\title{
Author Correction: The Seminavis robusta genome provides insights into the evolutionary adaptations of benthic diatoms
}

\author{
Cristina Maria Osuna-Cruz, Gust Bilcke (D), Emmelien Vancaester (D), Sam De Decker, Atle M. Bones, Per Winge, \\ Nicole Poulsen, Petra Bulankova (D), Bram Verhelst, Sien Audoor, Darja Belisova, Aikaterini Pargana, \\ Monia Russo (1), Frederike Stock (D), Emilio Cirri, Tore Brembu (1), Georg Pohnert (D), Gwenael Piganeau (1), \\ Maria Immacolata Ferrante (1), Thomas Mock (D), Lieven Sterck, Koen Sabbe (1), Lieven De Veylder (1), \\ Wim Vyverman (1) \& Klaas Vandepoele (1)
}

Correction to: Nature Communications https://doi.org/10.1038/s41467-020-17191-8, published online 03 July 2020.

In the original version of this Article, under the Methods subsection "DNA extraction and genome size estimation", the availability of the benthic diatoms used in this study and the accession number of the genome-sequenced strain were omitted. The first sentence, "Both Illumina and PacBio technologies were used for sequencing of S. robusta D6 strain mating type plus (MT+) to take advantage of short-read (better quality) and long-read (better contiguity) sequencing approaches", should be replaced by "The S. robusta D6 reference strain (accession number DCG 0498) and the 48 additional strains used in this study are available from the BCCM/DCG diatom culture collection at Ghent University (http://bccm.belspo.be/about-us/bccm-dcg). Both Illumina and PacBio technologies were used for sequencing of the D6 strain (mating type plus $(\mathrm{MT}+)$ ) to take advantage of short-read (better quality) and long-read (better contiguity) sequencing approaches". This has been corrected in both the PDF and HTML versions of the Article.

Published online: 16 October 2020

\footnotetext{
(c) Open Access This article is licensed under a Creative Commons Attribution 4.0 International License, which permits use, sharing, adaptation, distribution and reproduction in any medium or format, as long as you give appropriate credit to the original author(s) and the source, provide a link to the Creative Commons license, and indicate if changes were made. The images or other third party material in this article are included in the article's Creative Commons license, unless indicated otherwise in a credit line to the material. If material is not included in the article's Creative Commons license and your intended use is not permitted by statutory regulation or exceeds the permitted use, you will need to obtain permission directly from the copyright holder. To view a copy of this license, visit http://creativecommons.org/licenses/by/4.0/.
}

(C) The Author(s) 2020 